ENTREPRENEURSHIP AND SUSTAINABILITY ISSUES

ISSN 2345-0282 (online) http://jssidoi.org/jesi/

2019 Volume 7 Number 2 (December)

http://doi.org/10.9770/jesi.2019.7.2(15)

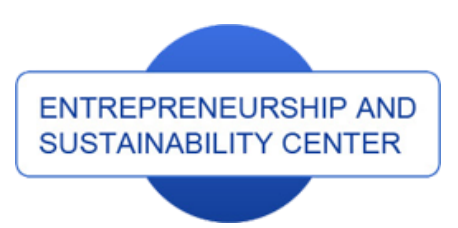

Publisher

http://jssidoi.org/esc/home

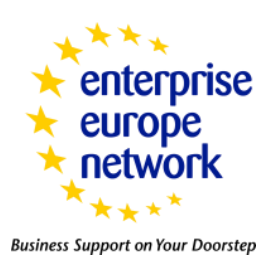

CASPA

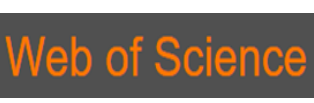

1) Clarivate

Analytics

\title{
EXPLORATION OF BARRIERS FACED BY FEMALE GRADUATE ENTREPRENEURS IN
} BANGLADESH

\section{Md Asadul Islam*1, Amer Hamzah Jantan², Abigail Hunt ${ }^{3}$, Md. Ferdausur Rahman', Mirza Manirajah Abdullah ${ }^{5}$}

1,2 Universiti Putra Malaysia, Serdang, 43400 Seri Kembangan, Selangor, Malaysia

${ }^{3}$ University of Lincoln, Brayford Pool, Lincoln LN6 7TS, United Kingdom

${ }^{4}$ Military Institute of Science and Technology, Dhaka 1216, Bangladesh

${ }^{5}$ Hanfiq Resources Ltd, George Town-10250, Penang, Malaysia

E-mails.: ${ }^{*}$ asadul.uos@gmail.com (corresponding author); ${ }^{2}$ amerhamzah@upm.edu.my, ${ }^{3}$ abhunt@lincoln.ac.uk, ${ }^{4}$ ferdaus806@gmail.com,${ }^{5}$ mirzapaa@yahoo.com

Received 15 May 2019; accepted 10 September 2019; published 15 December 2019

\begin{abstract}
This study explores and examines barriers faced by female graduate entrepreneurs founding and growing SMEs in Bangladesh. It particularly seeks to address the current gap in the literature on the barriers faced specifically by female graduate entrepreneurs in Bangladesh, and is among the first of its kind. We conducted 12 semi-structured interviews including 6 graduate female entrepreneurs of SMEs and 6 scholars in entrepreneurship in Dhaka, Bangladesh, and found that educated, graduate, females faced more barriers than uneducated or non-graduate females because of their educational background. It appears from our research that those women who had graduated from university were more likely to join in a company rather than starting and continuing to develop their own business. In addition to these key findings, we also found that Bangladeshi female graduate entrepreneurs had a lack of negotiation and pitching skills, little confidence, little access to institutional training and courses on SMEs and entrepreneurship. They also faced barriers such as lengthy, biased, and expensive loan facilities, corruption, operating in a conservative culture, a lack of support from their families and partners, barriers in mobility caused by traffic congestions in Dhaka, and risks to personal security. All of our findings from the interviews are well supported by additional research in the form of scientific observations of 79 entrepreneurs and 20 private and 5 public universities. The practical implications of these barriers are discussed in the paper and recommendations offered to key stakeholders to facilitate female graduate entrepreneurs in opening and operating SMEs in Bangladesh.
\end{abstract}

Keywords: female graduate entrepreneurs; barriers; SMEs; stakeholders; Bangladesh

Reference to this paper should be made as follows: Islam, M. A., Jantan, A. H., Hunt, A., Rahman, Md. F., Abdullah, M.M. 2019. Exploration of barriers faced by female graduate entrepreneurs in Bangladesh. Entrepreneurship and Sustainability Issues, 7(2), 10001014. http://doi.org/10.9770/jesi.2019.7.2(15)

JEL Classifications: A23, L21, L25, L26, L31 


\section{ENTREPRENEURSHIP AND SUSTAINABILITY ISSUES}

ISSN 2345-0282 (online) http://jssidoi.org/jesi/

2019 Volume 7 Number 2 (December)

http://doi.org/10.9770/jesi.2019.7.2(15)

\section{Introduction}

It is generally considered easier than ever for both males and females to start their own businesses in most countries across the world, but it is accepted that in the current environment the real barrier is for people is to in order to sustain and progress these businesses (Coleman, 2016; Burns, 2016; Cole, 2018). It is also accepted that educated people, regardless of their gender, have more potential to be successful entrepreneurs (Fenton, \& Barry, 2011; Lipset, 2018). This can be attributed to a range of factors inhibiting less educated people including technological advancement, business set up processes, getting permission from respective government offices, and accessing loans from banks. In addition to these issues there is also evidence to suggest that educated people are also more aware of business opportunities in the market (Fenton, \& Barry, 2011; Cesaroni and Sentuti 2016; Lipset, 2018). Entrepreneurs are currently considered as the main individuals who constitute modern global economic development (Kirschoff and Phillips, 1989; Keeble et al., 1990; Audretsch and Fritsch, 1991). They achieve this by generating ideas for new business ventures that utilise new or existing products or services, financial models, people, and/or equipment and facilities, contributing positively to the economy in the process (Donnely et al, 1990). Not only do many entrepreneurs aim to be profitable, but many also have a social conscience and create employment opportunities for different people regardless of gender, donation, or innovation, whilst simultaneously increasing competition in the market (Chell, 2013; Yunus, 2017; Hamdan, 2019). Thus, participation of females in the private and public companies established by different entrepreneurs has been increased in recent years throughout the world especially in developing countries such as those across South Asia (Kunze, \& Miller, 2017; Baird, Ford, \& Hill, 2017). For example, two decades ago women in Bangladesh made up only $10 \%$ of the labour force, whereas they currently comprise more than $40 \%$ of it (Byron and Rahman, 2015; Bangladesh Bank, 2017). The rise in the number of women in the country's labour force can largely be attributed to a 'private industry revolution' caused by the increased number of entrepreneurs establishing companies across industries and services in Bangladesh (Islam, 2009; Yunus, 2017). Despite this economic change and increased numbers of women in the labour force, the employment of the graduates in Bangladesh is very low in comparison with other countries in South Asia. For example in $201530 \%$ of graduates in India and Pakistan were unemployed, whereas in Bangladesh 50\% of graduates were not in employment (Asadullah, 2015). This high level of unemployment has been identified as an issue in relation to sustainable development in Bangladesh and a solution is needed urgently if the country's economy is to continue to develop (Asadullah, 2015). According to Yunus, (2017), encouraging graduates to engage in entrepreneurship by establishing and operating small and medium enterprises (SMEs) can be an effective solution to the issue of graduate unemployment, creating a job for the entrepreneur along with additional jobs for other graduates. One outcome of this activity is the acceleration of economic growth. This approach could help to address the issues seen in Bangladesh with evidence from The Daily Star (2015) suggesting that there is the potential to do this, as there are already 79,754 SMEs with more than 6 million workers in Bangladesh. Furthermore, opening a SME with a small amount of capital is relatively easy in Bangladesh, which means this opportunity should be accessible to a number of people and could be implemented as a strategy to lessen the problem of high numbers of unemployed graduates in the country (SME Foundation Survey, 2006-07; MIDAS, 2009; Islam, 2009; Fatima and Ahmed, 2017). Accordingly, many male and female graduates have opened SMEs in different districts of Bangladesh but generally their performance is limited in terms of revenue earnings and organisational growth (SME Foundation Survey, 2006-07; MIDAS, 2009; Islam, 2009; Fatima and Ahmed, 2017). This reflects the more global problem identified earlier in the introduction, and has resulted in several studies examining the barriers faced by the SME entrepreneurs in Bangladesh to grow their business (SME Foundation Survey, 200607; MIDAS, 2009; Islam, 2009; Fatima and Ahmed, 2017). However, there is a distinct gap in the specific empirical research relating to barriers faced by female graduate SME entrepreneurs in terms of opening and operating SMEs in Bangladesh, because there are no previous studies that explore the barriers faced by this specific group of people. If we consider that females make up $49.4 \%$ of the population in Bangladesh, $4 \%$ of the graduate population, and $50 \%$ of the body of unemployed graduates in the country then it is clear that this study to 


\section{ENTREPRENEURSHIP AND SUSTAINABILITY ISSUES}

ISSN 2345-0282 (online) http://jssidoi.org/jesi/

2019 Volume 7 Number 2 (December)

http://doi.org/10.9770/jesi.2019.7.2(15)

specifically identify the barriers female graduate entrepreneurs face in opening, growing and sustaining SMEs in Bangladesh and to provide potential solutions to these issues is essential (Khatun, 2018). It is already known that female entrepreneurs run many SMEs in Bangladesh and contribute positively to the country's economy (Asadullah, 2015; Pramanik, 2018), however very few of these are female graduates (Sultana, 2018; Pramanik, 2018), and it has been argued that the growth and sustainability of their companies may be hindered by their lack of education (Chowdhury, 2007; MIDAS, 2009; Bakht and Basher, 2015). There is the potential, then, to grow Bangladesh's economy in a sustainable way by introducing more SMES founded and led by female graduate entrepreneurs, something that might be facilitated by better understanding and removing the barriers they face (Chowdhury, 2007; MIDAS, 2009; Bakht and Basher, 2015). This study aims to do this by exploring:

1) What are the barriers female graduates face when opening a SME in Bangladesh?

2) What are the barriers female graduates face when operating SMEs in Bangladesh?

3) How these barriers can be overcome in relation to female graduates in Bangladesh?

There have been many female graduates, who have started SMEs in Bangladesh, however, the barriers they face in opening and operating their business have not previously been empirically researched. Hence, female graduate entrepreneurs and academic experts were interviewed as part of this research project to provide detailed information relating to the main barriers that create barriers to opening and operating SMEs in Bangladesh.

\section{Literature review}

\subsection{SMEs in Bangladesh}

It is recognised that Bangladesh is one of the fastest developing countries in South Asia, and is heavily dependent on SMEs for economic development, job creation, and knowledge expansion (Abdin, 2014; Habib, 2015; ADB, 2016; Yunus, 2017). For example the Asian Development Bank Institute (2016) stated that 99\% of formal Bangladeshi business enterprises are SMEs and it is a well cited fact that SMEs have created employment for around 75\% of non-agricultural workers in Bangladesh (ADB; 2016; Bangladesh Bank, 2017; Abdin, 2017). In addition to the impact on employment levels SMEs contribute more than 25\% to the national GDP of Bangladesh (ADB; 2016; Bangladesh Bank, 2017; Abdin, 2017). The Bangladesh Bureau of Statistics (2016) showed the contribution of SMEs to the country's GDP was 30.42\% in 2014-15 and it increased to 31.54\% in 2015-16. To boost the sector the Bangladeshi Government and its central bank have actioned integrated initiatives to promote SMEs and have tried to instigate improved levels of success lacking in the SME sector (Bangladesh Bank, 2019).

As this study concentrates on the barriers faced by female graduate SME owners specifically in Bangladesh, the tabular definitions of SMEs have been adopted from the Bangladeshi National Standard (see below Table 1) (Bangladesh National Industrial Policy, 2016). However, it is recognised that SMEs are defined differently in terms of capital and employment in the European Union (EU) and other countries. For example the standard EU definition states that an SME comprises fewer than 250 employees with less than $€ 50$ million turnover (EU, 2016), while in India a SME is defined as an organisation that has Rs. 25 lakhs ( ${ }^{\approx}$ US \$ 0.04 million) to Rs. 10 crores ( $\approx$ US\$1.6 million) turnover (SME Chambers of India, 2019). In Australia and New Zealand SMEs are defined as being organisations with up to 200 full-time equivalent employees (Dcmsme.gov, 2019). It is clear that there is no uniform worldwide definition of SMEs (Megginson et al, 2003; Omor and Ismail, 2009), because each country or region use their own measurement according to their level of development (Bilal and Mqbali, 2015). This disparity and specificity to a country's economic development status means that there is no value in challenging the localised definition of a SME or in trying to apply another country's definition to those in Bangladesh. In fact, it is crucial to work within Bangladesh's framework to ensure that this research can have a practical impact. 


\section{ENTREPRENEURSHIP AND SUSTAINABILITY ISSUES}

ISSN 2345-0282 (online) http://jssidoi.org/jesi/

2019 Volume 7 Number 2 (December)

http://doi.org/10.9770/jesi.2019.7.2(15)

Table 1. Definitions of SMEs in Bangladesh

\begin{tabular}{|c|c|c|}
\hline Sector & $\begin{array}{c}\text { Replacement Cost } \\
\text { (BDT=Bangladeshi Taka) }\end{array}$ & $\begin{array}{c}\text { Employed Manpower (not } \\
\text { above) }\end{array}$ \\
\hline Service & $50,000-50,00,000$ & 25 \\
\hline Business & $50,000-50,00,000$ & 25 \\
\hline Industry & $50,000-1,50,00,000$ & 50 \\
\hline \multicolumn{2}{|c|}{$\begin{array}{c}\text { Note: USD 1= BDT 82 } \\
\text { Source: Bangladesh Bank (2017) }\end{array}$}
\end{tabular}

\subsection{Major barriers faced by entrepreneurs in Bangladesh}

Whilst there are differences in terms of defining what an SME is in relation to its size and labour force, it appears from the literature that the barriers SMEs face relating to setting up and growth are similar globally. Kuratko and Hodgets (1995) established that the key barriers for SMEs are opportunity orientation; tolerance of failure; human relations skills; initiative and responsibility; integrity and reliability; internal locus of control; technical competence; high achievement drive; and mental ability. Existing literature suggests that these barriers have not changed in the last 23 years and are represented worldwide in studies from the 1990s onwards. For example Foon and Eu-Gene, (2006); Saleh and Ndubisi, (2006); Bardasi and Guzman, (2007); MIDAS; (2009) Bilal and Mqbali, (2015); Chowdhury, et al, (2015), all identified these problems in their studies. However, new barriers have also emerged from their studies that include political constraints, lack of infrastructure, corruption, low productivity, laws and regulations, and a lack of clear guidance and policy for the development of the sector. On the other hand, it has been widely acknowledged in these studies that opening a SME in different countries is easier and less expensive than a private limited company or partnership venture. Therefore it can be surmised from the literature that the barriers SME entrepreneurs face in Bangladesh, regardless of gender, are similar to other countries globally.

A key difference in experience between Bangladesh and other countries is that females in Bangladesh face more difficulties in running their SMEs in comparison with men (Bardesi and Guzman, 2007; MIDAS, 2009; Alaudin and Chaowdhury, 2015). Difficult and lengthy access to finance, poor infrastructures, high costs and lack of marketing facilities are the most significant barriers for the SMEs in the Bangladesh (Shakantu et al, 2007; Bahkt and Basher, 2015; Fatima and Ahmed, 2017). Bahkt and Basher (2015) and Ghosh, et al, (2017) identified SMEs owned or managed by women are discriminated against by institutional finance bodies, and poor social acceptability of females as business owners is also another hindrance for the development of female-owned SMEs in Bangladesh. However, it has been established that in developing economies like Bangladesh SMEs can be an alternative driving force for economic growth and should be supported (Hasan and Jamali, 2014; Chowdhury, et al, 2015, Fatima and Ahmed, 2017). In this regard, educated people particularly graduates i.e. males or females can be vital part of the growth establishing SMEs rather than working for a corporation or another business owner if they are given necessary support to manage the barriers we have identified in our research (Chowdhury, 2007; MIDAS, 2009; Bakht and Basher, 2015). According to the literature, significant studies have been done to recognise and highlight the barriers faced by entrepreneurs in Bangladesh and other countries. However, it is not clear from these studies what particular factors create barriers for numerous Bangladeshi female graduates when opening and operating a SME. Therefore, this study aims to identify those barriers so that the Government of Bangladesh and other development partnering countries and organizations can take action to encourage more female graduates to set up their own SMEs. 


\section{ENTREPRENEURSHIP AND SUSTAINABILITY ISSUES}

ISSN 2345-0282 (online) http://jssidoi.org/jesi/

2019 Volume 7 Number 2 (December)

http://doi.org/10.9770/jesi.2019.7.2(15)

\section{Methodology}

The empirical basis for this study is structured from qualitative research carried in the research context described above. A convenience sampling method was used to select the participants because it offered the flexibility to reach a number of participants. The location for data collection and observation i.e. Dhaka was selected because of convenient access to participants and time and budget limitations (Yin, 2009), which was considered appropriate for an exploratory research project. Over 3 months, 6 female entrepreneurs and 6 scholars were interviewed with semi structured questions and the researchers observed 79 entrepreneurs, 20 private, and 5 public universities (Rahman, Billah and Hack- Polay, 2019). Hence, the paper critically examines results extracted from the interviews and observations. All participants were Bangladeshi citizens living in Dhaka from different districts of the country. The graduate female entrepreneur participants were selected based on the educational qualification and duration their SMEs had been in operation. The baseline qualification for the study was an undergraduate degree, with 3 (or 50\%) of the participants holding a bachelors degree, and the remaining $50 \%$ of the participants Masters' degree holders. The scholars who participated in the study were university lecturers and professors with expertise in SMEs and entrepreneurship. The names of the participants have been changed in the paper to protect their identities. All interviews were recorded in English therefore translation was not required. As this research utilised a small sample of interviewees, the primary data were anyalsed manually and we concentrated on identifiying themes that arose from the interviews. We did this by reviewing the transcripts and coding the themes, which allowed us to group the themes together for analysis and discussion.

\section{Research findings and analysis}

This section includes the presentation and analysis of the primary data gathered during the research. It addresses not only emerging themes linked to the barriers female entrepreneurs in Bangladesh face in setting up and operating SMEs, but also how they have overcome these barriers. This key information informs our recommendations on practical initiatives that can be taken to facilitate SME creation and support its operation.

\subsection{Barriers in opening SMEs}

\section{Economic Barriers}

All the respondents of the study outlined interesting points regarding economic barriers in opening SMEs. Most of them confirmed, in line with existing literature, that there are few economic barriers in opening a SME in Dhaka, Bangladesh, because little start-up capital is required. For example, if anyone has only 50000 taka in Bangladesh they can start a business and it will be classified as an SME. All of the participants outlined that after graduation collecting the few thousand taka was not a barrier for them, therefore, starting a small business is relatively easy in this respect. This finding is consistent with previous research results published by the SME Foundation Survey, (2006-07); MIDAS, (2009); Islam, (2009); Fatima and Ahmed, (2017).

\section{Cultural Barriers}

The strongest barriers the female graduate entrepreneurs interviewed for this research faced in starting a business in Bangladesh were cultural. This is much in line with the main barrier faced by females in starting a business in South Asian Countries highlighted in the United Nations Economic and Social Commission for Asia and the Pacific (ESCAP) report (2013) and Organisation for Economic Co-operation and Development (OECD) report (2017). The first cultural issue noted by all 6 participants was the female manager or owner being out of place in the business environment, Participant 6 summed this experience up well when she said,

"Women potential as successful business magnet is not taken in our society positively since most of the people like us to be at home rearing children and doing households works". 


\section{ENTREPRENEURSHIP AND SUSTAINABILITY ISSUES}

ISSN 2345-0282 (online) http://jssidoi.org/jesi/

2019 Volume 7 Number 2 (December)

http://doi.org/10.9770/jesi.2019.7.2(15)

This is consistent with the research results of the studies by Rahmatullah and Zaman (2014), Islam and Jantan, (2017) and Masuda and Chowdhury, (2017) who have also found that particular societies do not respond positively to female success in business and would prefer females to be at home undertaking household duties. Further to the idea that the women were operating outside their traditional societal roles, all of the female graduate entrepreneur interviewees perceived the societal norm of early marriage as a key barrier to overcome and open a SME in Bangladesh, for Example Participant 4, said,

"In our culture most of the females, either educated or not, assumed to be married as soon as they in suitable age and after their marriage they are rarely inspired to open a business that creates the most difficult and negative barrier for a women to open a SME in the different industry in spite of her interest and potentiality".

This finding is also consistent with previous studies such as Chowdhury et al, (2015), Islam and Jantan, (2017) and OECD, (2017) who all found that it is a societal preference in South Asia and Bangladesh for women to be married at a young age and assume a traditional domestic role.

\section{Social Barriers}

Whilst the female entrepreneur participants highlighted cultural issues, practical barriers in setting up a SME particularly linked to the cultural context were elicited from the scholars' responses during the interviews. In this regard, Participant 8 opined that

"The lack of negotiation and pitch skill is one of the key barrier that needs to be removed from the students to make them successful entrepreneurs and in terms of female graduates this is more common since Bangladeshi society is a conservative cultural society where girls are not allowed to speak up in most cases even though they are educated".

In addition, Participant 10 added that

"An entrepreneur not only has to develop a business and starting business but also pitch this to different panel for example to the banks to take loans, to the government administrative officers to get government benefits and so on. In this regard, without the entrepreneurship and business related courses, students get very few ideas about the business venture therefore they face barrier to start a SME or any other kind of business organization".

The rest of the scholars who participated in the research raised similar concerns regarding the lack of negotiation and pitching skills and the barriers this creates for graduate female entrepreneurs who endeavour to open and operate their SMEs in Bangladesh. For example, they emphasized the need to convince both male and female students to develop these skills through different processes. Their emphasis on the process of developing negotiation and pitching skills mirror the researches by Clark (2008), Eddleston et al, (2006), Chell, (2013), Chang and Rieple, (2013) and Mamabolo et al, (2017).

The observations by the researchers mirrored the social barriers for female graduates setting up SMEs that were recognised by participants in interviews. However, our observations highlighted that there very few universities in Bangladesh that organise business start-up workshops for students and there is a general lack of support available to graduates who want to open their own business. Conversely, most universities do organise job fairs for their recent graduates attracting many local and international private and public companies that inspire the graduates to join in a company rather than starting their own SME. Based on this observation all the scholars and the 


\section{ENTREPRENEURSHIP AND SUSTAINABILITY ISSUES}

ISSN 2345-0282 (online) http://jssidoi.org/jesi/

2019 Volume 7 Number 2 (December)

http://doi.org/10.9770/jesi.2019.7.2(15)

entrepreneurs were asked if establishing start-up workshops or seminars and support by universities would be helpful or not for students, regardless of their gender. All of them answered that if universities offered these types of activities they would be able to inspire female students to start a SME rather than going to work for an established company after their graduation.

\section{Political Barriers}

A lack of Government administrative support for encouraging the set-up of SMEs for graduate females was recognised by all 6 entrepreneurs. This was exemplified by Participant 3 who said that

"The government and non-government supporting news in newspapers and the public programs held in our area inspired me to be an entrepreneur, however, my practical knowledge about their helps in opening and operating the Corner Shop is very dippersful specially in taking loans from government owned banks and high interest of NGOs and Co-Operative loans along with lengthy process".

Similar opinions were provided by other 3 participants such as Participant 2, Participant 1, and Participant 5 interviewed in this study. However, Participant 5 specifically added that

"Government officials support only to the persons, who supported the ruling government parties during the election! As a result, the business women like us, who are not involved in politics directly, never get support from the government officials and representatives".

This is consistent with Islam, (2009), Bakht and Basher, (2015) Chowdhury et al, (2015) who also identified that there is a lack of government support and motivation for female graduates to be entrepreneurial.

\subsection{Barriers in operating the SMEs}

\section{Economic Barriers}

Whilst no economic barriers were identified in the setting up of a SME, all 12 of the participants identified financial constraints as the most significant barrier for graduate female entrepreneurs when operating their businesses. Participant 3 mentioned that

"Studying in Bangladesh particularly in private universities is very expensive that is financed by parents in most cases. After the graduation of students, most of the parents want their graduate children to earn money immediately to hold the financial responsibility of the family or return the money that has been spent for study. Therefore, after graduation opening a SME or any other organisation is tough, however, it is sometimes overcome but operating the organisation for long time becomes difficult and challenging. For example, I do not get any financial support for my SME from family and even to get loan from public bank is lengthy and bias while the getting loan is easier from NGOs or other financial organizations but very expensive due to high interest rate".

This is similar to previous results of research conducted by Bahkt and Basher (2015) and Ghosh, et al, (2017) who found a general lack of support for women from the financial organizations. For example, they identified that bank managers are not very comfortable in lending money to female entrepreneurs. This is also consistent with other previous studies for example Cesaroni and Sentuti (2016) found that in the context of Italy, a person's gender impacts on banks' decision making around lending for the purposes of operating a business. However, our result contrasts with a report that the Bangladesh government (published by Bangladesh Bank, 2019) equally distributes loans and other economic support to both male and females. Therefore, our results urge the 


\section{ENTREPRENEURSHIP AND SUSTAINABILITY ISSUES}

ISSN 2345-0282 (online) http://jssidoi.org/jesi/

2019 Volume 7 Number 2 (December)

http://doi.org/10.9770/jesi.2019.7.2(15)

government to monitor the current situation of loan disbursement and other economic support for female entrepreneurs.

\section{Cultural Barriers}

Cultural barriers for female graduate entrepreneurs are similar in operating SMEs to those faced when establishing a business, something that was commented on by all the participants. Participant 6 outlined how societal and family expectations create obstacles in operating SMEs. She said

"In our society even in urban areas where most educated people live expect females regardless of their degrees or qualification, skills or passion to continue business, should remain at home people to perform family responsibilities such as rearing children, preparing foods and so on. As a result, due to lack of cooperation comes from the society as well as family members.

Furthermore, Participant 4 added

"Although a graduate female overcomes the barriers in opening the SMEs or any business but after her marriage, family responsibilities and lack of cooperation from husband and other members of family do not allow to continue the business. As a result, a dream dies very silently and it has been common in many cases. For example, I had two friends, who started small business of selling jute products and beauty salon but they closed businesses due to lack of family cooperation and inspiration.

The insights derived from Participant 4 and Participant 6 were similar to other respondents and these are also consistent with previous studies such as Islam and Jantan, (2017) and Masuda and Chowdhury, (2017) who outlined that females are not supported by their families and Bangladeshi society when trying to run a business. Furthermore, Chowdhury et al, (2015) and OECD, (2017) have reported similar findings in relation to cultural barriers in operating a SME in Bangladesh. However, with the advancement of the technologies and literacy rate in Bangladesh there is the potential for societal norms to be barrierd and these barriers to be reduced, but this has not been done by government officials and is a cause for concern. A further cultural barrier is one of security for women. Participant 7 agreed with the view of Participant 2 in case of security issue and quoted that "moving in Dhaka City alone with a handbag is very dangerous especially in evening and morning times". Both of them added that this security situation for women has a negative impact on the business operations.

\section{Social Barriers}

Participant 5 and Participant 3 and Participant 9 were concerned regarding the social issues specially the costs of traffic jam and risky transportation in the social environment where they run SMEs. However, Participant 9 said that

"Traffic jam and risky transportation with high expensive tickets are also most of the barrier that should be removed from the country to create easy market environment for the entrepreneurs especially for the graduate female entrepreneurs".

Participant 8 added that

"There are also some over-highlighting job advertisements in different mediums, however, opportunities for graduate to join there is very limited. But these allure graduates particularly female graduates to apply for job and wait for the result that takes a long time. As a result, the graduate loss interest to start a business rather than continuing applying in the different organizations to get a job". 


\section{ENTREPRENEURSHIP AND SUSTAINABILITY ISSUES}

ISSN 2345-0282 (online) http://jssidoi.org/jesi/

2019 Volume 7 Number 2 (December)

http://doi.org/10.9770/jesi.2019.7.2(15)

In contrast, Participant 5 outlined

"Not getting job was the motivation for me to start a business but my friends, who joined in the banks rather than starting a business, are in good position with good income therefore it attracts me to close down my SME since competition and political uncertainty is increasing day by day".

This view is supported from the response of Participant 10 that

"Joining and being permanent in a job especially in a multinational company or public organization gives financial security for a graduate along with a secure future with a lump sum amount of pension in the bank. Therefore, some students after their graduation start business but when they find huge difficulties and challenging due to political turmoil, mismanagement of government offices, lack of family supports, market competition etc. they tend to leave the business and try to join in a company. There are substantial opportunities for experienced people with business knowledge therefore the graduates become interest to join in the company in most cases due to the barriers they face in operating their SMEs".

All the social barriers derived from the participants in this section are in contrast to previous studies where job availability and secure future for a job holder, traffic jam, and risky transportation have not been highlighted as a social barrier. Therefore, this study has been a significant contribution for the respective decision makers for example government in Bangladesh to motivate or facilitate women to start a business rather than joining in a job.

\section{Political Barriers}

Political uncertainty, strikes by political and even non-political organisations, and autocratic attitudes have been identified as the political barriers faced by SMEs' owners in operating. It is reflected from the response from Participant 5, who said

“Government uncertainty, ruling party's pressure on opposition, students politics, strikes have been regular in Bangladesh, thus, these create obstacles to keep their business open regularly".

Similarly, all the participants provided similar data regarding the political barriers in operating SMEs in Bangladesh. This result is consistent with previous studies, for example Chowdhury, et al, (2015) and Alauddin, M. D., \& Chowdhury, M. M. (2015) and Hasan \& Jamil, (2014). It is likely that this similarity is because Bangladesh has had the same ruling party for over a decade, but there is the potential for lobbying to ask them to take a new stance on supporting female graduate entrepreneurs.

\subsection{Overcoming the barriers}

The participants suggested areas that could be addressed to overcome the barriers in opening and operating SMEs by female graduates in Bangladesh. Bangladesh has experienced tremendous improvement in the digitalisation of the different aspects of society including public organizations (UN, 2017; FT, 2017). However, there is no online registration for SMEs and no data on entrepreneurs/owners of SMEs shared digitally by the government department responsible for SMEs. The scholars in this study suggested that the government need to utilise digital resources to create an online registration process for SMEs, noting that this approach could remove biasness, and reduce the lengthy and expensive process of opening and operating these economic enterprises. This view was also held by female graduate entrepreneurs who participated in the study. Participant 3 said that 


\section{ENTREPRENEURSHIP AND SUSTAINABILITY ISSUES}

ISSN 2345-0282 (online) http://jssidoi.org/jesi/

2019 Volume 7 Number 2 (December)

http://doi.org/10.9770/jesi.2019.7.2(15)

"Digitalisation of SMEs registration will contribute to get loans and other supports from the banks and other financial sources without running to submit papers and details most frequently in different offices because respective offices, required for information to take decision on SMEs and their owners, can get the data in the SME portal".

All of the participants placed an emphasis on the importance of a need for training and seminars on entrepreneurship and different business opportunities in Bangladeshi universities and colleges. Participant 11 said that

"Most of the universities and colleges organise job fair adjunct with different private companies to attract the talented students to join in the different vacant positions. However, it is rare that the universities and colleges have organised business opportunity fairs for the graduates. Therefore, regular business opportunity fair could be very effective to stimulate graduates specially females to start a SME rather than looking for job. This will also be effective platform to identify the barriers, which could be faced in opening and operating a business while possible solutions could be clarified. As a result, the existing and potential entrepreneurs would be start and continue their business specially in SME sector of the Bangladesh".

Participant 9 said that

"At present there are only entrepreneurship course and trainings under the business and management faculties in the universities but students from other faculties also pose potentiality to be a successful entrepreneurs. However, there are very few training programs and courses relating to entrepreneurship in those faculties therefore the students are not inspired to open a small and medium enterprise (SME). Hence, organising those programs would be effective to motivate graduates from science, law, and other faculties to start a business especially in SME sector since it is easier than other sectors".

All of the 6 female graduate entrepreneurs and scholars that participated in the study highlighted the importance of the need for changes in attitudes towards female entreprenurship in terms of both among individuals and society. This is perhaps one of the most significant barriers to women wanting to open and operate SMEs in Bangladesh today. Participant 5 added that

Husbands and parents should be supportive to female counterparts so that they can use their talent for themselves rather than working for others to give better outcome for family and society and finally the country".

According to the results highlighted in this section regarding overcoming the barriers barriers in opening and operating SMEs, the following suggestions can be outlined for the attention of respective authorities (in particular the Bangladeshi Government) :

1) Digitalisation of registering SMEs and loan disbursement for SME entrepreneurs.

2) Organising training and seminars on business opening and operating processes.

3) Short courses for all students on entrepreneurship in the universities.

4) Attiudinal changes in society towards female entrepreneurship.

5) Organising business opportunity workshops in universities for the fresh graduates or the students from different faculties including business, law, tourism, science, medical etc. 


\section{Key themes emerging}

In summary, the 6 graduate female entrepreneurs and 6 scholars interviewed offered a range of answers to the questions of the study. They simultaneously identified a number of the barriers in opening a SME in Bangladesh, with their responses cooberating one another. These barriers include gender stereotyping, lengthy registration process, bias and ambiguous government administrative system, lack of support from their families and/or partner, complicated start-up capital support from the banks and other financial institutions, and a lack of negotiations and pitching skills.

Barriers stemming from the operational processes of SMEs in Bangladesh include lack of loans to finance when needed, lack of security, bias and lengthy process of getting financial supports, traffic jam, risky and expensive transportation, job opportunities for experienced people with qualification, and the competitive market environment.

Though not explicitly stated, the theme running through many of the interviewees' responses was that there are a number of reasons, which create difficulties and barriers in both opening and starting a SME in Bangladesh. The entrepreneurs and scholars participated in the study felt that they should not accept this situation because it needs to be changed and removed to facilitate the opening and operating SMEs by the talented people, especially by female graduate entrepreneurs.

\section{Concluding Remarks}

This study aimed to identify the barriers faced by graduate female employees in opening and operating SMEs in Bangladesh so that respective stakeholders such as government, policy makers and others can take action to overcome the barriers in the country. The barriers hindering the graduate female entrepreneurs and others to open a SME or other business came out of this study are:

- Gender stereotyping lengthy registration process.

- Bias and ambiguous government administrative system.

- Lack of partner and parents' supports.

- Lack of start-up capital,

- Rare and complicated start-up capital support from the banks and other financial institutions.

- Lack of negotiations and pitching skills.

The barriers creating obstacles in operating the established SMEs in Bangladesh are:

- Lack of capital for SMEs.

- Lack of security.

- Congestion.

- Expensive transportation.

- Government mismanagement.

- Opportunities for jobs for graduate and experienced entrepreneurs since they possess practical experience from being an SME owner.

- Market competition.

The suggestions made by the participants to overcome the barriers in case of opening SMEs included digitalisation of SMEs registering, loan disbursement, finding supportive partners for encouragement, and individual changes. In the case of operating SMEs founded in Bangladesh the suggestions derived from interviewees included facilitating loan disbursement for entrepreneurs, creating supporting environment in government offices, improving security, developing transpiration and reducing the fare of transports as well 


\section{ENTREPRENEURSHIP AND SUSTAINABILITY ISSUES}

ISSN 2345-0282 (online) http://jssidoi.org/jesi/

2019 Volume 7 Number 2 (December)

http://doi.org/10.9770/jesi.2019.7.2(15)

traffic jam in Dhaka city where it is regular and most difficult phenomenon for city dwellers as well. Finally, graduate female entrepreneurs should barrier the paradigm of overall challenging circumstances to be successful although this is not without risk to personal and professional posture.

\section{Practical implications}

The government of Bangladesh needs to take more realistic initiatives to reduce and eradicate the barriers that are faced by the graduate female entrepreneurs in opening and operating SMEs in Bangladesh. There is great potential for female created and managed SMEs to operate successfully and contribute to the GDP, but this is currently limited because of the issues raised in this paper. This research shows that most of the students have the potential to be successful entrepreneurs in different sectors. However, it is identified that government systems, sophisticated, expensive and unfair financial sources, logistical issues, and a lack of family support are key obstacles in both opening and starting the SMEs in the country. A key question then is what can different stakeholders such as government, bank authorities, NGOs, and also to the entrepreneurs can do about these? An online discussion between 3 of the academic participants and 4 of the female graduate entrepreneurs, that followed the interview process, came up with a number of factors that should be considered by these authorities to facilitate the SME opening and operating processes:

- Improve the digitalisation for easy registering and entrepreneurs' information collection and sharing with different co-authorities such as banks. In this regard, online a secure form and entrepreneurs' profile could be effective,

- Offer easily accessible loans for entrepreneurs according to their business plans and reduce the interest of loans for graduate female entrepreneurs,

- The Government should monitor loan disbursement to make sure the right candidate receives it rather than depending on inaccurate information on the loan distribution among the different SMEs owners and others,

- Every university and college can organise entrepreneurship courses and trainings to provide practical knowledge to the graduates and potential graduates on how to open SMEs and operate them efficiently,

- Family members such as parents, husbands and others of graduate female entrepreneurs and potential graduate entrepreneurs should be convinced regarding the significance of female entrepreneurship for the individual and social benefits that would stimulate those people to be supportive to the graduate female entrepreneurs. In this regard, the government can take initiatives for example seminar on this context in different areas of Bangladesh to make people aware and motivated to express positive attitude and become co-operative.

- Graduate female entrepreneurs should have energy to sustain in the challenging contexts to be successful with their SMEs.

\section{Limitations and Future Directions}

Like most studies, the present study does have some limitations, particularly regarding the nature data collection and the size of the sample. During the data collection, the interviewer's personal attributes such as gender, age, profession and experience, could have influenced the participants' behaviour and responses. The nature of this study means participants might have been hesitant to discuss sensitive issues regarding barriers that are faced by graduate female entrepreneurs for fear of jeopardising their own careers. However, the confidentiality of participants was ensured to help counter this. The study included only 12 interviews, therefore, the outcome of the research cannot be generalized, but in future, the identified barriers can be applied in the survey to make the results generalizable. Moreover, a further, more in depth, study could be conducted among different ethnic groups of female graduate entrepreneurs to identify the barriers they face in opening and operating business. Furthermore, the results could be compared with, or tested in, other country contexts where the female entrepreneurship has been increasing with great potential. 


\section{ENTREPRENEURSHIP AND SUSTAINABILITY ISSUES}

ISSN 2345-0282 (online) http://jssidoi.org/jesi/

2019 Volume 7 Number 2 (December)

http://doi.org/10.9770/jesi.2019.7.2(15)

\section{References}

Abdin, M. J. (2014). Vision-2021: The Role of Small and Medium Enterprises in Bangladesh Economy. http://dx.doi.org/10.2139/ssrn.2465763

ADB. (2016). ADB to Privide Loans to SMEs, Women Entrepreneurs in Rural Bangladesh. https://www.adb.org/news/adb-provide-loans$\underline{\text { smes-women-entrepreneurs-rural-bangladesh }}$

Ahmed, K., \& Chowdhury, T. A. (2009). Performance evaluation of SMEs of Bangladesh. International journal of Business and Management, 4(7), 126-133. https://doi.org/10.5539/ijbm.v4n7p126

Alauddin, M. D., \& Chowdhury, M. M. (2015). Small and Medium Enterprise in Bangladesh-Prospects and Barriers. Global Journal of Management and Business Research, 15(7), 1-10. https://globaljournals.org/GJMBR Volume15/1-Small-and-Medium-Enterprise.pdf

Baird, M., Ford, M., \& Hill, E. (Eds.). (2017). Women, Work and Care in the Asia-Pacific. $1^{\text {st }}$ ed., Routledge, London.

Bakht, Z., and Basher, A. (2015). Strategy for Development of the SME Sector in Bangladesh. Bangladesh Institute of Development Studies, 1-40.

Bangladesh Bank. (2019). SME Loan Disbursement. Government Report of Bangladesh. https://www.bb.org.bd/aboutus/dept/sme/sme_factsnfigure.php

Bardasi, E., Blackden, C.M. and Guzman, J.C. (2007). Gender, entrepreneurship, and competitiveness in Africa, Chapter 1.4 of the Africa Competitiveness Report, June 26, The World Bank, http://citeseerx.ist.psu.edu/viewdoc/download?doi=10.1.1.497.4003\&rep=rep1\&type=pdf

Bilal, Z. O., \& Al Mqbali, N. S. (2015). Barriers and constrains faced by small and medium enterprises (SMEs) in Al Batinah governorate of Oman. World Journal of Entrepreneurship, Management and Sustainable Development, 11(2), 120-130. https://doi.org/10.1108/WJEMSD-05-2014-0012

Cesaroni, F. M., and A. Sentuti. (2016). Economic Crisis, Women Entrepreneurs and Bank Loans: Some Empirical Evidence from Italy. Economic Research, 29(1), 1050-1061. https://doi.org/10.1080/1331677X.2016.1211953

Chang, J., and Rieple, A. (2013). Assessing students' entrepreneurial skills development in live projects. Journal of Small Business and Enterprise Development, 20(1), 225-241. https://doi.org/10.1108/14626001311298501

Clark, C. (2008). The impact of entrepreneurs' oral 'pitch' presentation skills on business angels' initial screening investment decisions. Venture Capital, 10(3), 257-79. https://doi.org/10.1108/17506200710779549

Chowdhury, M. (2007). Overcoming entrepreneurship development constraints: the case of Bangladesh, Journal of Enterprising Communities: People and Places in the Global Economy, 1(3), 240-251.

Chell, E. (2013). Review of skill and the entrepreneurial process. International Journal of Entrepreneurial Behavior \& Research, 19(1), 631. https://doi.org/10.1108/13552551311299233

Chowdhury, M. S. A., Azam, M. K. G., \& Islam, S. (2015). Problems and Prospects of SME Financing in Bangladesh. Asian Business Review, 2(2), 51-58. https://journals.abc.us.org/index.php/abr/article/view/4.8Chowdhury

Cole, N., (2018). Young Entrepreneurs, This Is How You Start A Profitable Business. https://medium.com/@nicolascole77/youngentrepreneurs-this-is-how-you-start-a-profitable-business-d1eeb7eb1e6

Coleman, A. (2016). How technology has changed the lives of entrepreneurs through the ages. https://www.virgin.com/entrepreneur/howtechnology-has-changed-lives-entrepreneurs-through-ages

Eddleston, K.A., Friar, J.H. and Clark, E. (2006). Pitching to the home shopping network: an exercise in opportunity assessment and personal selling, Organization Management Journal, 3(3), 257-70. https://doi.org/10.1057/omj.2006.24 


\section{ENTREPRENEURSHIP AND SUSTAINABILITY ISSUES}

ISSN 2345-0282 (online) http://jssidoi.org/jesi/

2019 Volume 7 Number 2 (December)

http://doi.org/10.9770/jesi.2019.7.2(15)

ESCAP. (2013). Overview of the Environment for Women's Entrepreneurship in South Asia. http://www.unescap.org/sites/default/files/Women-Entrepreneuship-South-Asia-Policy-Dialogue.pdf

Fenton, M., \& Barry, A. (2011). The Efficacy of Entrepreneurship Education. Industry and Higher Education, 25(6), 451-460. https://doi.org/10.1080/03075079.2017.1365359

Ghosh, P. K., Ghosh, S. K., \& Chowdhury, S. (2017). Factors hindering women entrepreneurs' access to institutional finance-an empirical study. Journal of Small Business \& Entrepreneurship, 30(4), 279-291. https://doi.org/10.1080/08276331.2017.1388952

Halkias et al. (2011). Barriers facing women entrepreneurs in Nigeria. Management Research Review, 34(2), .221-235. https://doi.org/10.1108/01409171111102821

Hasan, F., \& Jamil, G. M. H. (2014). Financing Small and Medium Enterprises in Bangladesh-Issues and Barriers. The Asian Journal of Technology Management, 7(1), 45-54. https://globaljournals.org/GJMBR_Volume15/1-Small-and-Medium-Enterprise.pdf

Habib, S. (2015). SME Financing and it's importance of our economy. A study on IDLC Finance LTD. BRAC University Press. http://dspace.bracu.ac.bd/xmlui/handle/10361/4542

Hamdan, A. M. M. (2019). Entrepreneurship and Economic Growth: An Emirati Perspective. The Journal of Developing Areas, 53(1), 6578. https://doi.org/10.1353/jda.2019.0004

Islam, S. M. (2009). Start-up and growth constraints on small-scale trading in Bangladesh. Journal of Chinese Entrepreneurship, 1(3), 227239. http://etd.uum.edu.my/7230/2/s95879_02.pdf

Islam, M. A., \& Jantan, A. H. (2017). The glass ceiling: Career barriers for female employees in the Ready Made Garments (RMG) Industry of Bangladesh. Academy of Strategic Management Journal, 16(3), 1-11. https://www.abacademies.org/articles/The-glass-ceilingcareer-barriers-for-female-employees-1939-6104-16-3-141.pdf

Khatun, F. (2018). Women's participation in the job market. https://www.thedailystar.net/supplements/womens-participation-the-job$\underline{\text { market-1545181 }}$

Kundu, S., and Rani, S. (2016). Female aspirant human resources' entrepreneurial orientation. Management Research Review, 9(2), 235263. https://doi.org/10.1108/MRR-11-2015-0267

Kunze, A., \& Miller, A. R. (2017). Women helping women? Evidence from private sector data on workplace hierarchies. Review of Economics and Statistics, 99(5), 769-775. https://doi.org/10.1162/REST_a_00668

Lipset, S. M. (2018). Values, education, and entrepreneurship. In Promise of Development. Routledge, London.

Masuda, M., and Chowdhury, R. (2017). Barriers for women entrepreneurs. [Online] http://www.thedailystar.net/educationemployment/barriers-women-entrepreneurs-1366573

MIDAS. (2009). Women Entrepreneurs in SMEs: Bangladesh Perspective. Copy of Final SME Report. http://bids.org.bd/uploads/events/almanac2018/TS-2 P-3.pdf

Mamabolo, M. A., Kerrin, M. \& Kele, T. (2017). Entrepreneurship management skills requirements in an emerging economy: A South African outlook. Southern African Journal of Entrepreneurship and Small Business Management, 9(1), 1-10. https://doi.org/10.4102/sajesbm.v9i1.111

Megginson, L. C., Byrd, M. J. and Megginson, W. L. (2003). Small Business Management: An Entrepreneur's Guidebook, $4^{\text {th }}$ ed., McGraw-Hill, New York.

Meyer, D. S. and Debra C. M. (2004). Conceptualizing Political Opportunity. Social Forces, 82, 1457-1492. https://doi.org/10.1353/sof.2004.0082

Meyer, J. W. (2000). Globalization: Sources and Effects on National States and Societies. International Sociology, 15, $233-248$. 


\section{ENTREPRENEURSHIP AND SUSTAINABILITY ISSUES}

ISSN 2345-0282 (online) http://jssidoi.org/jesi/

2019 Volume 7 Number 2 (December)

http://doi.org/10.9770/jesi.2019.7.2(15)

Omar, S. S. and Ismail, M. (2009). The background and barriers faced by the small medium enterprises. A human resource development perspective. Journal of Business and Management, 4(10), 95-102. https://doi.org/10.5539/ijbm.v4n10p95

OECD. (2017). Strengthening Women's Entrepreneurship in ASEAN. Available at: http://www.oecd.org/southeast-asia/regionalprogramme/Strengthening_Womens_Entrepreneurship_ASEAN.pdf

Pramanik, S. A. K. (2018). Developing women entrepreneurship in Bangladesh. Available at: http://m.theindependentbd.com/printversion/details/175224

Rahmatullah, M., and Zaman, F. (2014). Female Entrepreneurship in Bangladesh: Constraints, Motivation and Success, Bangladesh eJournal of Sociology, 11(2), 65-77. http://www.bangladeshsociology.org/5.11.2.pdf

Saleh, A. S. and Ndubisi, N. O. (2006). SME development in Malaysia: domestic and global barriers. Faculty of Business-Economics Working Papers. University of Wollongong.

Sultana, N. (2018). Women entrepreneurs have huge potentials. Available at: http://www.theindependentbd.com/arcprint/details/70690/2016-12-02

Yunus, M. (2017). Entrepreneurship: A Global Social Movement. Sage Publications.

Md Asadul ISLAM is a PhD candidate at Faculty of Economics and Management at Universiti Putra Malaysia (UPM). He has been working on women leadership development in Bangladesh and Malaysia. He has published several research papers relating to women leadership in the context of ready-made garments industry in Bangladesh. He is also doing research on human resource management, green human resource management, millennials' intention to stay and organisational behaviour.

ORCID ID: http://orcid.org/0000-0002-2420-3705

Abigail HUNT is Dr., Head of Department for Marketing and Tourism in the Lincoln International Business School, the University of Lincoln. Her expertise are in developing alternative, or new, narratives on well-covered topics through qualitative research. She has an interest in gender studies having researched, presented, and published on female and child labourers in the agricultural sector in the UK.

ORCID ID: http://orcid.org/0000-0002-0788-2785

Amer Hamzah JANTAN is Dr., a senior lecturer at the Faculty of Economics and Management at Universiti Putra Malaysia (UPM). His expertise areas include leadership, strategic management, human resource management and entrepreneurship.

ORCID ID: https://orcid.org/0000-0003-1519-4584

Md. Ferdausur RAHMAN is a Major in Army, Dr., an Associate professor of Military Institute of Science and Technology (MIST), Bangladesh. He has research and teaching experiences for more than sixteen years under different reputed universities. His work focuses specifically on micro-financing and their impact on socio-economic development.

ORCID ID: https://orcid.org/0000-0002-9456-9681

Mirza Manirajah ABDULLAH is Dr., a senior consultant at Hanfiq Resources Ltd, Penang, Malaysia. His area of research includes human resource development in organisations in the modern era. He has been working on industry 4.0 and entrepreneurship.

ORCID ID: https://orcid.org/0000-0002-0712-8838

Copyright (C) 2019 by author(s) and VsI Entrepreneurship and Sustainability Center

This work is licensed under the Creative Commons Attribution International License (CC BY).

http://creativecommons.org/licenses/by/4.0/

(c) (7) Open Access 